\title{
The Unpopularity of Property Law Modules: Popular Culture offers Solutions
}

\author{
By Anna Chronopoulou*
}

\begin{abstract}
The commodification of Legal Education and the popularity of law as a subject of study have been reflected in a plethora of law courses at undergraduate and postgraduate levels on offer in the English Universities. Property Law modules do not necessarily enjoy the same degree of popularity to other modules on a qualifying law degree in English Universities. Despite being slowly changing modules, Property Law modules did not remain unaffected by the commodification of legal education. As a result, Property Law became highly specialised. This quickly translated in optional modules such as: Succession Law, Housing Law, Landlord and Tenant Law, Construction Law etc. Nevertheless, Property Law modules remain highly unpopular among the student population in the English Universities. This paper examines the reasons for this by focusing on three parameters. The first parameter examines the nature of the subject itself as highly technical, therefore less adventurous and attractive. The second parameter brings forward the suggestion that neither legal educators nor researchers have actually successfully managed to break away from the monotony of Property Law subjects. The third parameter proposes solutions to the increasing unpopularity of these subjects. It puts forward the suggestion that a socio-legal approach to the subjects combined with appealing forms of popular culture might just increase the popularity of the subjects among the student population.
\end{abstract}

Keywords: Legal Education, Property Law modules, Popular Culture

\section{Introduction}

Legal education has experienced a number of transformations in England and Wales over the last decades. The transformation from classical to ascribed criteria demarcated the renegotiation of the classical knowledge mandate. The increased specialisation of areas of legal practice led to the commodification of legal education with a wide range of legal subjects on offer at undergraduate and postgraduate level ${ }^{1}$. This was sustained through an unprecedented popularity of law as a subject of study. As a result, this influenced the growing number of law students from wider sections of society and possessing different social characteristics in terms of gender, class, race and age entering law schools in English Universities ${ }^{2}$.

The increasing demand of the study of law led to the production and consumption of a great number of law programmes, ranging from general legal

\footnotetext{
"PhD (Law), Senior Lecturer in Equity, Westminster Law School, the University of Westminster, London, UK.

${ }^{1}$ Collier (2005).

${ }^{2}$ Sommerlad (2007). The same claim is put forward in a number of articles, see by way of reference Sommerlad, Webley, Duff, Muzio \& Tomlinson (2010).
} 
studies to criminology and more recently Commercial law oriented programmes at all levels, in the English Universities. Although most of the aforementioned programmes have enjoyed a great degree of popularity, it would be naïve to suggest that Property Law oriented modules and programmes fall in this category. The commodification of legal education affected the slowly changing nature of Property Law modules in a number of ways. In reflecting specialisation, Property Law modules seemed to have suddenly surpassed the numerical limitations distinguishing between Property Law I, commonly referred to as: Land Law and Property II usually referred to Equity and Trusts. Individual areas of property law which in turn reflected areas of specialisation were quickly designed and redesigned as optional modules such as: Succession Law, Housing Law, Landlord and Tenant Law, Construction Law etc. Despite the incredibly sophisticated packaging, Property Law modules still remain highly unpopular among the student population in English Universities.

This paper examines the reasons for this by focusing on three parameters. The first parameter explores the highly technical nature of Property Law, which makes it less adventurous and appealing to students. The second parameter examines the attitude of legal educators and researchers towards Property Law subjects. The third proposes solutions to the increasing unpopularity of these subjects. It puts forward the suggestion that a socio-legal approach to the subjects combined with appealing forms of popular culture might just increase their popularity among the student population.

\section{Property Law Subjects and their Nature}

The nature of Property law subjects has not exactly been the easiest of tasks to deal with. They are considered to be slowly changing subjects, nevertheless, extremely substantive resembling almost the black letter approach to law, which enhances their unpopularity amongst the student population ${ }^{3}$.

Traditionally, property law subjects comprise Land Law and Equity and Trusts both subjects are considered core modules for a qualifying law degree in England. Also traditionally, property law subjects have always been associated with solicitors' work commonly known as conveyancing ${ }^{4}$. From this perspective both subjects are closely associated not just with lawyers' work and what lawyers do but also they are inextricably linked to the history of the legal profession in England and Wales something that could not offer a justification for their unpopularity taking into consideration that every English Law School at the moment produces lawyers.

Property Law deals mainly with the registration of interests that govern land and the English soil therefore it is mainly concerned with legal interests. Equity and Trusts again a property law subject deals mainly with the regulation of equitable interests. Land law comprises endless legislative and case law provisions attaching a highly technical feel to the module. Equity and Trusts

\footnotetext{
${ }^{3}$ Hudson (2015).

${ }^{4}$ Abel (1988). See also Abel (1999) and Abel (2003).
} 
the other component of the Property based modules, the core ones, does not exactly fall short behind. Apart from the difference in the nature of interests, however, Equity and Trusts is also heavily crammed with a great number of case law acquiring in this sense a highly technical feel to it. Both modules do possess a highly slowly changing nature in terms of case law and legislative intervention. The suggestion here is that the highly technical and slowly changing nature of the Property Law modules make them unpopular amongst the student population. The highly technical nature of the property law subjects disassociates them from the social, encouraging a form of a-sociality or even adiaphorisation and disinterest in regards to the modules making it even harder for the subjects to claim back their role and importance within the social context ${ }^{5}$. It is exactly this disassociation from the social that makes Property Law subjects less and less popular amongst law students.

Generally speaking, the commodification of legal education and of the provision of legal services has not left Property Law subjects and modules unaffected. More specifically, the commodification of property law subjects has seen itself in being broken down to a plethora of specialisation subjects of property law such as Housing Law, Landlord and Tenant, Construction Law ${ }^{6}$. In other words, every single area that used to have been offered by then as part of the Property modules due to specialisation has started being offered on its own. Nevertheless, the nature of those modules as well has followed the complicated nature of the core Property Law modules increasing from this perspective the unpopularity of the modules overall. The mould of these modules did not break away from the usual way that these modules have been offered and organised reinforcing in this sense the unpopularity of the modules amongst the student population. Across the board the subjects remain highly technical in nature as well as promoting a black letter, substantive approach rarely if ever being mixed with aspects of theoretical approaches.

To a great extent this is also an issue of the highly complicated substantive nature of the subjects due to the common law system itself based upon the lack of codification creating confusion in this sense ${ }^{7}$. Despite the repeated attempts of the legislator to make the subjects less complicated it seems that the introduction of recent Acts just for the regulation of interests has even complicated the subjects further. The attempts from the European legislation and regulation have not been necessarily implemented to the study and nature of Property Law modules. Despite the codification provided by the EU legislation this has not been implemented either properly or in parts at all. Retaining in this sense the sovereignty of not just English Property Law but of the land as well. The latest developments in the referendum after Brexit are highly likely to complicate things in Property Law Modules even more. The reason for this is that is that the simplification of codification applying in Civil Law Jurisdictions, through EU Law limited of course nevertheless existent will not be there anymore for Britain.

\footnotetext{
${ }^{5}$ Goodrich (1996). See also Goodrich (2000).

${ }^{6}$ Hudson (2015).

${ }^{7}$ Hudson (2015).
} 
Although the situation with Brexit remains to be seen, despite this having influenced the property market this remains still outcast in the sphere of commercial awareness rather than an actuality of justifying the unpopularity of property law modules. For the time being, it looks like what Brexit has affected in the sphere of property market is the prices of commercial as well as residential properties whether for lettings or for sale. While the property market has been grind to a halt and Great Britain feels smaller than ever, funnily enough this has not managed to push up the popularity of the subjects. Needless to say that the battering the property market has taken after Brexit has even deteriorated the situation with the relevant modules popularity rendering them even more unpopular.

Apart from the recent developments as far as Brexit is concerned there has always been an undisputed factor as to the students' attitudes in regards to the liking of the modules of Property Law. It has to be said and submitted that these subjects have never enjoyed the popularity that the Criminal law options have enjoyed. The reason for this is not just the technical nature of the subjects because Criminal law is fairly technical itself. However, it is increasingly popular amongst the student population. It is submitted here that one of the main reasons that the subjects enjoy unpopularity is the fact that Property Law modules have never been made as seductive and attractive to the students as Criminal Law modules have been made ${ }^{8}$. Another point that needs to be made here is the fact that although Criminal law is highly unlikely to touch people's lives in the way that property law does it still remains a mystery why Property law modules are deemed so unpopular.

If we are to claim that Criminal law is aesthetically appealing to the student population simply because of the matter of promotion then it is fair to say that Property Law modules have not enjoyed that much of a promotion so to become popular. It might also be that simply Property Law modules lack an ethics of aesthetics ${ }^{9}$. They completely and utterly lack aestheticization. As a result they become less appealing to the student population. One of the main reasons for the unpopularity of the modules on Property Law is the high degree of difficulty associated to these modules ${ }^{10}$. Nevertheless, it is submitted that English Law and commonwealth jurisdictions have a very similar way of dealing with certain subjects and modules, which is normally fairly straightforward and consists of the application of the relevant case law and statutory provisions. Therefore the

\footnotetext{
${ }^{8}$ Hudson (2015). It is submitted, however, that despite there are notable exceptions Hudson's work is one of them that with constant reference to pop culture the nature of the Property Law modules becomes a bit more bearable.

${ }^{9}$ Maffesoli (1991). The notion of ethics of aesthetics is inextricable linked to Michel Maffesoli's work referring usually to modes of anesthetisation. The notion is deployed here for the purposes of the lack of a form of aesthetics in the nature of Property Law modules.

${ }^{10}$ Penner (2016). Even from the very early stages in his book Penner comments on the difficulty of the module of Equity and Trusts he claims: "Trusts is a gripping subject. Unfortunately it grips most students with anxiety. There is a good reason for this: it is difficult. Almost every topic in the law of trusts is complicated by demanding intellectual problems about the correct solutions by which academics and judges alike disagree"
} 
aforementioned argument becomes weak and extremely inappropriate as to the degree of difficulty attached to Property Modules.

To a great extent might be the students' attitudes as to the nature of the subjects themselves. For example, the greater percentage of law students are slaves to the reputation of the subject. This is not helping as usually these subjects do not have the greatest of reputations. This sounds like a chicken and egg situation since reputations are strictly associated with the popularity of the subjects. Hence, if a subject is unpopular there is no way that it has a good reputation amongst the students' population. Reputations are not very difficult to be created through and in a Law School. There is usually a high degree of communication between the students at all levels ${ }^{11}$. Also nowadays in the electronic era that news travels fast it only takes a split of a second for Property Law subjects to gain and retain a bad reputation. Usually it is very difficult to get out of and nearly impossible to deal with or even try and battle with. Bad reputations of a subject are usually impossible to reverse and overcome amongst the students' population. It is highly at odds however, now entirely with the students' attitudes especially after the introduction of really high tuition fees by every singly University in the England. What is at odds with the ethics as well as the aesthetics of the legal profession is that historically these subjects the property law subjects were the bread and butter of every singly solicitor in the UK since the early history of the legal profession. In fact Property Law forms part of the historical tradition of the legal profession and is strongly associated with it. From this perspective, it is very difficult to fathom as well as imagine the unpopularity of the Property Law Modules amongst the student population.

It is possible, however, that despite the historical association of the subjects to the work of the legal profession, these has been substituted by the commodification of the legal profession in the UK and also the increasingly profit making nature of other subjects like commercial law subjects for instance. Nevertheless, this can also be set aside as an argument from the point of view that commodification has also affected Property Law subjects. There is a Commercial side to Property summarised as commercial transaction in Property Law and deals with commercial dealings only. So from this perspective, the disassociation of Property Law from the historical tradition of the legal profession does not necessarily provide a valid explanation and examination to the matter at hand. On the contrary, if anything it should have boosted the popularity of the subject simply because of its commercial side to it as well as its association with the historical aspects of the legal profession. If we are to accept that education has become a means to an end which justifies the increase in the tuition fees as well as a different attitude amongst the student population towards a profit making overall attitude then it follows that the commercial side to property law reinforces this ${ }^{12}$. However, what needs to be seriously taken into consideration is that Property law deals no matter how commercial in nature or not do not necessarily have the same appeal to law students as the large commercial deals that have nothing to do with Property. Studies reveal that the majority of law

\footnotetext{
${ }^{11}$ Garbado \& Gulati (2000).

${ }^{12}$ Kennedy (1992).
} 
students strive to become corporate lawyers ${ }^{13}$. In this kind of job there is no place for property law deals no matter how commercial in nature they are.

Another parameter that needs to be examined here is the very fact that despite the commercialisation of the modules, property law subjects/modules need serious revamping that hardly anyone is willing to risk let alone attempt. A number of reasons can be provided for this. Firstly and most importantly, it is seen a highly time consuming task that given the number of the cohorts of the law students in the English Universities, it is hard to believe that more time will go to a revamping of the syllabus, the opposite rather. Another possible reason is that the nature of the modules is so dry that it is disheartening to even begin to attempt a revamping of these modules. Instead a traditional and dry approach is usually adopted to the modules that makes it even harder for the students to follow and more importantly take a shine to. There is nothing aestheticized about it and it is even more possible that the closest that it ever gets to aesthetics is the use of an equally dry series of power point slides reflecting the very nature of the modules.

\section{The Absence of Aestheticized Aspects in Property Law Modules}

Aesthetics ${ }^{14}$ in its ancient Greek meaning entails a sensuous approach to education. This sensuous approach that is evident in the teaching of other modules is hardly ever evident in the teaching of the property law modules. Hardly ever the case that land becomes aestheticized surprisingly enough given the day to day mundane going to the University and basically stepping or walking on a piece of land. These kind of examples hardly ever make it in textbooks which are equally dry a tendency that is easily transferred to the teaching of property law modules in large lecture theatres or even smaller seminar classrooms. Ironically enough property law modules are the epitome of the presence of the absence not just in a Derridean sense but in every possible sense of the word. A more emphatic absence is felt in the module of Equity and Trusts complementing the second one of the property modules taught on every LLB degree offered in the UK. The very nature of the module is abstract nevertheless, it is completely absent from everyday life. It is not something the students can identify with or even recognise in everyday transactions. It has nothing to do with the financial term equity used in commercial transactions. Equity and Trusts as a module carries with it ideas of natural justice, fairness even maxims ${ }^{15}$ that today's generation are either unfamiliar with or carefully chose to ignore. In this sense the module is presently absent its only presence is being felt through the disastrous usually success rate in almost every University in the country. Students find it hard, almost impossible to say the very least to grasp, therefore they hardly ever take a shine to the module ${ }^{16}$. The only presence that it is being felt in regards to

\footnotetext{
${ }^{13}$ Collier (2005). See also Collier (2006).

${ }^{14}$ Maffesoli (1991). See also Maffesoli (2007).

${ }^{15}$ Hudson (2015). See also Penner (2016).

${ }^{16}$ Hudson (2015). See also Penner (2016).
} 
the module is its very presence in the syllabus of every qualified law degree, as a core module. Equity, therefore becomes necessity. It is a necessary module, a gatekeeper to a law degree. It is just another one of the core modules, usually termed the students' nightmare before the dream, the desired qualifying law degree opening the doors to a highly successful career usually as a commercial solicitor or a barrister. Law students in the UK have to go through it. They have to battle against its abstract nature. They have to deal with abstract notions such as conscience and unconscionability, something that really prevails the law and amends law's mistakes only that it is not exactly visible. It does not necessarily involve the senses as it is invisible, a completely different system that is not visible in the naked eye. Maybe it has something to do with everyday life yet again not really. Possibly, it is around them in the form of charities again involving a noblesse oblige, a noble mentality but it does not exactly enjoy the visibility and aesthesis of law. It dances on the edge of a paraesthesis, an illusion, of an abstract core module almost invariably lacking definitions, being associated rather often than not with philosophy, legal philosophy and a very uncommon law. Equity cannot be felt, cannot be seen cannot be tasted, nor heard, it can only be tested.

From another perspective, however, the only aesthetics applicable to Property Law modules is through teaching. This is where Equity and Land Law can really be heard, tasted, felt, touched upon and tested in the end. This is where aesthetics hints at a sensuous approach to teaching. Sensuality is used here in exactly what the term describes as aesthesis, hearing, seeing, touching, feeling ${ }^{17}$ etc. Where the modules come alive on and off the stage of the lecture theatre where property law modules become a spectacle. Or maybe not, judging from the low numbers of attendance, the constant nightmare of the fellow academics colleagues throughout every single term duration, adding to the bad reputation of the property modules and to their unpopularity among the student population. This alludes to the constant challenge every single lecturer faces which is usually summed up in the ways of engaging and enthusing the students. Maybe the frequently asked question on interview panels for academic jobs on enthusing law students into the study of property law modules would have been fairly simple through the use of the image and use of VLE. However, it is exactly the same answer that seems pointless when tackling the modules of property law. Where the image is reduced to a mere symbol playing a decorative role right next to a case simply adding some colourful touches to an otherwise black letter and fairly substantive approach to the teaching of the property law modules. The possibility of land law winning the prize here exceeds expectations as Equity and Trusts cannot be posited amongst the modules that are easily cartooned whatsoever.

Recommended textbooks do not necessarily escape the dry nature and reputation of the modules. Their highly decorated and adorned front covers attest to the fact that simply there is nothing fancy about them. They merely add another component to the dry nature of the modules. Adam Gearey contends that the study of the property law modules remains dry in every sense of the word ${ }^{18}$. From this

\footnotetext{
${ }^{17}$ Maffesoli (1991).

${ }^{18}$ Gearey (2017/18).
} 
perspective, innovation comes into play as a real challenge this time as it is a fierce fight up against the dry nature of Property Law modules. It is, at times, a personal bet to make the modules juicier by trying not to slavishly follow them. This, in many respects is a daunting task itself. If seen from a completely different perspective both Property modules, Land Law and Equity and Trusts constitute no exception to the traditional forms of legal education in play today on both sides of the Atlantic. Despite the popularity of aesthetic forms and in this sense more sensuous and at times sensual interpretation of law in practice, law students spend their lives in the law school committed to a systematic textual interpretation. Aesthetic forms requiring the presence of image remain tactfully hidden, relentlessly tacked away from law schools, with few exceptions, contradicting the multimedia world of contemporary organisational world of legal practice. Doctrinal study is viewed as more important, particularly given the limited time to cover the syllabus, often ten to twelve weeks. The gimmicky visual representations are not treated as facts and the fact-based art of legal persuasion remains profoundly a linguistic privilege. As a result, heavy reliance on textbooks in the teaching of both property modules attests to a reliable, less time consuming and less gimmicky way of approaching the teaching of the modules rather than relying on aestheticized forms of popular culture for example. Besides, the general assumption is that students are there to study law as they have already been socialised in general education at an earlier stage. Only to discover later that they lack critical thinking skills and that their general knowledge is limited. Surprisingly enough, the basic requirement of lawyers' work is to showcase understanding of the world around them. While this translates to a hands-on approach in legal education, teaching beyond what is formally acknowledged as law, hasn't made its way in the classroom yet.

\section{Land and Equity go pop}

The amalgam of law and popular culture hasn't always been easy to receive as a separate branch of research or to find its place in legal education and law schools on both sides of the Atlantic ${ }^{19}$. For many the aforementioned fusion has been deemed pervasive, if not laughable and for many others transgressive to say the very least ${ }^{20}$. It has only been in the recent years that law and popular culture has found a place in some exceptional law schools, which also constitute an exception, by way of certain research centres in England ${ }^{21}$. On the other side of the Atlantic the picture is largely similar, however, it is acknowledged that popular culture made its way more comfortably in the American legal education as

\footnotetext{
${ }^{19}$ Greenfield \& Osborne (2006). See also Redhead (1995) on the unpopularity of Pop Culture.

${ }^{20}$ Redhead (1995).

${ }^{21}$ The first centre in English Law Schools dealing with these important issues, was the Centre for Law and Popular Culture in Manchester Metropolitan University, created by Professor Steve Redhead in the Law School. Around the same time chronologically, Guy Osborn and Steve Greenfield create the Centre for Law, Society and Pop Culture at Westminster Law School. Years later a similar attempt results in the creation of the centre for Law and Culture at St Mary's University, Twickenham.
} 
opposed to the English Law Schools. Popular culture has been perceived as challenging the status of the law. Besides, it has always comprised something of a chthonian, subterranean and subcultural nature that debunks the very nature of law itself ${ }^{22}$. The legal profession has always perceived itself as distant from the masses, being part of a professional elite, socially representing a small section of the population. While this might have facilitated the resistance of law to popular culture, it seems that popular culture is acutely receptive to legal stories. For instance, representations of lawyers can be found in a number of films, TV series and literary works ${ }^{23}$. Gradually, portrayals of lawyers in literature and other forms of pop culture have become the subject of study in research centres specialising in law and pop culture on both sides of the Atlantic. Gradually pop culture made its way into law teaching but only in limited modules or as a module itself on both sides of the Atlantic ${ }^{24}$.

The question, however, remains as to the benefits of integrating popular culture into the teaching of Property Law modules? Property Law modules are inextricable linked with popular culture. For example, one of the essential characteristics of the definition of popular culture is public consensus. Similarly, conscience seems to constitute the main undercurrent theme in both Property Law modules, Land Law and Equity and Trusts. In this sense, popular culture can be seen as integrated in the curriculum due to Property Law modules. In other words, popular culture defines Property Law and vice versa. On the same note, popular culture proposes drawing parallels with reality. This alludes to the approach taken in legal education and the teaching of Property Law modules termed "hands-on", dealing with realistic situations and scenarios. From this perspective, popular culture could potentially facilitate a fresher approach and outlook on the everyday. Therefore, integrating popular culture into Property Law modules encourages the sensuous, the use of the senses and eventually recalls aesthetics back into the teaching of Property Law. It also reinforces the relation of the abstract to the real. In this sense, integrating popular culture in the teaching of Property Law offers students the ability to experience, to see clearly, how abstract Property Law notions are potentially, nevertheless, inextricably linked to their everyday lives.

Law students are usually socialised firstly into popular culture as consumers, before they even become law students, before they even enter Law School ${ }^{25}$, before they even start consuming Property Law textbooks. Embracing popular culture in the teaching of Property Law emphasises and reinforces the doctrinal approach to the module. Using popular culture approaches in the teaching of Property Law modules is appealing to today's law students, because they are habitual consumers of popular culture ${ }^{26}$. Allegedly, the unbearably intellectual lightness of popular culture makes Property Law modules more bearable, popular, and appealing to the law students' population. It is in this sense, as Friedman

\footnotetext{
${ }^{22}$ Greenfield \& Osborne (2006). See also on the unpopularity of Pop Culture Redhead (1995).

${ }^{23}$ Asimow (2018). See also Bailey (2018).

${ }^{24}$ Friedman (1989).

${ }^{25}$ Bailey (2018).

${ }^{26}$ Batlan \& Bass (2018).
} 
suggests popular culture as the doctrine itself becomes the lens through which to study the Law, to actually study Property $\mathrm{Law}^{27}$. Embedding popular culture in Property Law modules constitutes a way of engaging and enthusing law students to the study of Property Law by making doctrine more alluring and vibrant for them ${ }^{28}$. From this perspective, invoking pop culture becomes a necessity, which reaffirms the necessary doctrinal presence of the Property Law modules in the curriculum, not the other way around.

Incorporating forms of popular culture into the teaching of Property Law modules enhances law students' critical thinking and research skills. From this perspective, it enables law students to have a better grasp of complicated and abstract notions and a better understanding of the interrelation between legal and cultural aspects ${ }^{29}$. For example, requiring law students to research forms of popular culture relating to issues of Property Law provides them with a plethora of different perspectives on the sensuous aspects of these modules. In this sense what they do, see, hear and taste in the course of conducting research then relates to the concrete reality of the classroom. In other words, they learn, how to act and think like lawyers through researching forms of popular culture for the purposes of Property Law modules. It is usually these kind of activities that expose them to the way film and other forms of popular culture depict Property Law issues. In emphasising the benefits of incorporating popular culture in the teaching of Property law modules, it could be said that it can supplement theoretical and experiential teaching methodologies by allowing students to "see" processes they might otherwise never witness ${ }^{30}$. This in other words, emphasises a sensuous and experiential approach to the teaching of Property Law modules. Incorporating popular culture in Property Law modules introduces an element of surprise, potentially an element of humour into the classroom alleviating in this way the daunting nature of these modules ${ }^{31}$.

Incorporating forms of popular culture into the teaching of Property Law modules contests the deification of the courtroom. It breaks away from the dry nature of the modules by introducing elements that law students enjoy. It is not uncommon to use aspects of popular culture, such as clips out of films, full-length films in the teaching of law $^{32}$. Studies show that law students particularly enjoy watching and analysing films in law schools. It is perceived as a striking contrast from the typical, substantive approach usually adopted in the teaching of law. Increasingly, legal educators also use legally themed television shows in order to expose different pedagogical techniques and enthuse law students into the study of law. Nevertheless, this approach needs to be tested on other modules. The suggestion put forward for the purposes of this article is that legal educators

\footnotetext{
${ }^{27}$ Friedman (1989).

${ }^{28}$ Meyer \& Davis (2018).

${ }^{29}$ Corcos (2018).

${ }^{30}$ Sherwin (2018). See also Sassoubre (2018) and Papy (2018).

${ }^{31}$ Bailey (2018).

${ }^{32}$ Fisher (2018). See also Miller (2001). It is worth noting at this point that Miller's contribution is one of the notable exceptions to associating Pop Culture to the study or research of Equity and Trusts, together with Hudson's textbook. It is hardly ever the case that the module of Equity and Trusts is associated with any issues of Pop Culture in its entirety.
} 
need to broaden the range of modules in which aspects of popular culture are used as well as the range of forms of popular culture used. The use of appealing images ${ }^{33}$ and kinds of music can equally serve the purpose of engaging and enthusing law students in the study of highly unpopular modules such as Property Law. Incorporating forms of popular culture in the teaching and study of Property Law in other words, does not necessarily have to confine to the use of certain forms of pop culture ${ }^{34}$. An example could be the concept of home featuring in both modules, from a completely different perspective, Land Law and Equity and Trusts. A house that becomes a home, the buying and selling of a house or the breaking down and dissolution of a marriage and eventually of home, constitutes just some of the few main themes often depicted and portrayed in films, clips of songs and literary works.

The interdependence of the narrative, the storytelling in both popular culture and legal culture needs to be examined in order to assess the validity of incorporating pop culture in the teaching of Property Law modules ${ }^{35}$. Pop culture has always influenced the legal tradition and vice versa. In this sense the two are permeable. Legal narrative, legal storytelling has always borrowed from pop culture storytelling. It is the meeting of the two oral traditions in a sense. Legal narrative has constituted the main subject matter of many films, literature, TV series, comics etc. ${ }^{36}$ On the other hand, many stories that are told in the courtroom derive from pop culture. This can be subject to two interpretations. The first interpretation relates to the original definition of pop culture and refers to stories being narrated in the courtroom that refer to members of the public. The second interpretation refers to actually following the same aesthetics and architecture of the case resembling pop culture references found in movies and literature. From this perspective, using pop culture methodologies in the teaching of Property Law could potentially equip law students with the necessary skills required in modern day legal practice like the skills of persuasive storytelling ${ }^{37}$. This also alters the perception to the teaching of the modules. In this sense, Property Law modules become a storytelling process, which emphasises and embodies shared cultural mythologies and affinities. Property Law modules cannot be separated from the contexts that gave birth to the doctrines that constitute the main tools of experiential classroom. Pop culture references in the teaching of Property Law modules facilitate storytelling in visually engaging ways. The visualisation of information of pop culture in the teaching of Property Law, through the use of films, entailing colourful images ${ }^{38}$, ensures the promotion of interest and depth of learning. The main aim of this is simply to connect students of Property Law modules to what they already know. In other words, incorporating popular culture references to the teaching of Property Law Modules simply reconnects law students as popular culture members to processes of storytelling in law. This

\footnotetext{
${ }^{33}$ Porter (2018). See also Fisher (2018).

${ }^{34}$ Schulz (2018).

${ }^{35}$ Sassoubre (2018).

${ }^{36}$ Watkins \& Guihen (2018). See also Asimow (2018).

${ }^{37}$ Sassoubre (2018).

${ }^{38}$ Austin (2018).
} 
approach breaks away from a dry, logic deducting technique and reintroduces an aesthetic approach to the Property Law modules. The use of the word aesthetics in this case does not necessarily refer only to the senses, therefore relating only to the visual. It also relates to its connotation as emotion. Visual exercises through pop culture reference create the potential in Property Law modules for the law students to come to terms with the potential range of emotional as well as perceptual associations ${ }^{39}$. Incorporating pop culture references in the teaching of Property Law modules helps students not only to express themselves orally but also visually. Property Law modules in this sense become visually reconstructed and deconstructed by enriching the rule-based, case-driven legal curriculum.

Studies on law and popular culture have always fleshed out the hero and villain dichotomy, either when concentrating on the study of certain characters or when narrating the eccentricities of lawyers on the screen. This dichotomy is not that easily defined and clear cut when it comes to the storytelling of Property Law. It is almost non-existent, absent. However, it captures the layperson's attitude and eventually that aporia in Property Law. Law students who study these lay attitudes in law school can then incorporate them as they need to in their professional work later on. In that way, they can move closer to one of their goals, to be more capable and informed actors and representatives of the legal system. Popular culture creates a new topos ${ }^{40}$, place and space in the study of Property Law modules. After all the Greek meaning of the word topos has always been associated with the meaning of land, landscape, state and property. This topos can be reflected in the legal classroom as a means of a creation of inroads, a path to a different approach to the teaching of Property Law modules summed up in the amalgamation of the old with the new. The new narrative, the incorporation of popular culture, as Said and Silbey suggest, creates a renegotiation of the older narrative conventions and forms by shaping and forming new communications ${ }^{41}$. In the teaching of Property law modules the creation of inroads through the incorporation of popular culture amounts to a renegotiation of legal analysis of property law, to a reconnection in other words of these modules to new experiences of the present, while at the same time reflecting on the past. It creates a renegotiation of the legal skills that law schools on both sides of the Atlantic so proudly provide.

\section{Conclusion}

This article attempted to offer some explanations on the unpopularity of Property Law modules. It suggested that this unpopularity resides in the technical nature of the modules and the complete and utter lack of an aestheticized approach to them. It also suggested that this is due to the students' attributes and attitudes towards these modules. It also put forward the suggestion that one way of

\footnotetext{
${ }^{39}$ Fisher (2018). See also Mezey (2018).

${ }^{40}$ Said \& Silbey (2018).

${ }^{41}$ Fisher (2018). See also Mezey (2018).
} 
reintroducing aestheticization to these modules is through the incorporation of pop culture in the teaching of the modules. It also examined the potential benefits incorporating popular culture entails. Property law issues often feature in forms of popular culture. Apart from an amusing examination of legal stories, popular culture can provide useful insights into how actually Property Law operates. The aestheticization of Property Law modules provides the platform to equip and prepare future lawyers for the challenges of the modern day organisational practice. Proposing the incorporation of pop culture into the study of Property Law modules goes beyond taking popular culture seriously. Popular culture is not restrained to cinematic representations of lawyers and the legal system. Above all pop culture is constructed upon people's beliefs, opinions and customs in exactly the same way that Land Law and Equity and Trusts are.

\section{References}

Abel, R. L. (1988). The Legal Profession in England and Wales. Oxford: Basil Blackwell.

Abel, R. L. (1999). 'The Politics of Professionalism: The Transformation of English Lawyers at the End of the Twentieth Century' in Legal Ethics 2(2):131-147

Abel, R. L. (2003). English Lawyers Between Market and State-The Politics of Professionalism. Oxford: Oxford University Press.

Asimow, M. (2018). 'The Mirror and the Lamp: The Law and Popular Culture Seminar' in Journal of Legal Education 68(1):115-121.

Austin, R (2018). 'A Dose of Color, A Dose of Reality: Contextualizing Intentional Tort Actions with Black Documentaries' in Journal of Legal Education 68(1):45-54.

Bailey, W.S. (2018). 'Lessons from Pop Culture: What School of Rock Can Teach the School of Law' in Journal of Legal Education 68(1): 92-102.

Batlan, F. \& J. Bass (2018). 'Beyond Greed is Good: Pop Culture in the Business Law Classroom' in Journal of Legal Education 68(1):23- 30.

Collier, R. (2005). 'Be smart, be successful, be yourself...? Representations of the training contract and trainee solicitors in advertising by large law firms' in International Journal of the Legal Profession 12 (1):51-92.

Collier, R. (2006). 'Peter's Choice: Issues of Identity, Lifestyle and Consumption in Changing Representations of Corporate Lawyers and Legal Academics' in Greenfield, S. \& G. Osborne (eds) Readings in Law and Popular Culture. London: Routledge, pp.31-64.

Corcos, C.A. (2018). 'It All Started with Columbo: Teaching Law with Popular Culture' in Journal of Legal Education 68(1):122-128.

Cova, B., Kozinets, R.V. \& A Shankar (2007). Consumer Tribes. Oxford: ButterworthHeinemann.

Fisher, G. (2018). 'Evidence by the Video Method' in Journal of Legal Education 68(1):15-22.

Friedman, L.M. (1989). 'Law, Lawyers and Popular Culture' in Yale Law Journal, 98(8): 1579-1606.

Garbado, D.W. \& M. Gulati (2000). 'Conversations at Work' in Oregon Law Review 79:103-145.

Gearey, A. (2017/18). City Law School Equity and Trusts Module Guide 2017/18

Goodrich, P. (1996). Law in the Courts of Love: Literature and Other Minor Jurisprudences. London: Routledge. 
Goodrich, P. (2000). 'Law Induced Anxiety: Legists, Anti-Lawyers and the Boredom of Legality' in Social and Legal Studies 9(1):143-160.

Greenfield, S. \& G. Osborne (eds.) (2006). Readings in Law and Popular Culture. London: Routledge.

Griggs-Spall, I. \& P. Ireland (eds.) (1992). The Critical Lawyer's Handbook. London: Pluto Press,

Hudson, A. (2015). Equity and Trusts, $8^{\text {th }}$ ed. London: Routledge.

Kennedy, D. (1992). 'Legal Education as Training for Hierarchy' in Griggs-Spall, I. \& Ireland, P. (eds.) The Critical Lawyer's Handbook. London: Pluto Press. pp 51-61.

Maffesoli, M. (1991). 'The Ethic of Aesthetics' in Theory, Culture \& Society 8(1):7-20.

Maffesoli, M. (2007). 'Tribal Aesthetic' in Cova, B., Kozinets, R. V. \& A. Shankar Consumer Tribes, Oxford: Butterworth - Heinemann, pp. 27-34

Mezey, N.J. (2018). 'Teaching Images' in Journal of Legal Education 68(1):74-81.

Meyer, P.N. \& C.A. Davis (2018). 'Law Students Go to the Movies II: Using Clips from Classic Hollywood Movies to Teach Criminal Law and Legal Storytelling to FirstYear Law Students' in Journal of Legal Education 68(1):37-44.

Miller, W.I. (2001). 'Clint Eastwood and Equity: Popular Culture's Theory of Revenge' in A. Sarat \& T.R. Kearns (eds.) Law in the Domains of Culture. Ann Arbor, Michigan: The University of Michigan Press.

Said, Z.K. \& J. Silbey (2018). 'Narrative Topoi in the Digital Age' in Journal of Legal Education, 68(1):103-14.

Schulz, J.L. (2018). 'Expanding the Pie or Slicing the Bug? ADR Education via Animated Short' in Journal of Legal Education 68(1):31-36.

Sherwin, R.K. (2018). 'Visual Literacy for the Legal Profession' in Journal of Legal Education 68(1): 55-62.

Sommerlad, H (2007). 'Researching and Theorizing the Processes of Professional Identity Formation' Journal of Law and Society 34 (2):190 -217.

Sommerlad, H., Webley, L., Duff, L., Muzio, D. \& J. Tomlinson (2010). Diversity in the Legal Profession in England and Wales: A Qualitative Study of Barriers and Individual Choices. London: Legal Services Board.

Sassoubre, T.M. (2018). 'Visual Persuasion for Lawyers' in Journal of Legal Education 68(1):82-90.

Papy, D. (2018). 'Dr. Strangelaw, or How I Learned to Stop Worrying and Love Pop Culture' in Journal of Legal Education 68(1):129-135.

Penner, J.E (2016). The Law of Trusts. $10^{\text {th }}$ ed. Oxford: Oxford University Press.

Porter, E.G. (2018). 'Imagining Law: Visual Thinking Across the Law School Curriculum' in Journal of Legal Education 68(1):8-15.

Redhead, S. (1995). Unpopular Cultures: The Birth of Law and Popular Culture. Manchester: Manchester University Press.

Watkins, D. \& L. Guihen (2018). 'Using Narrative and Metaphor in Formative Feedback: Exploring Students' Responses’ in Journal of Legal Education 68(1):154-175. 